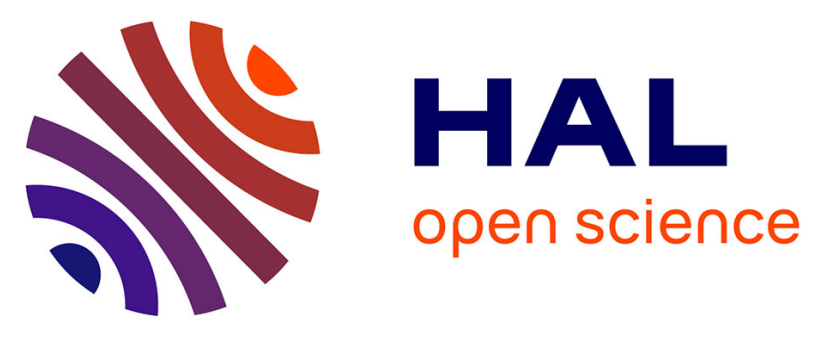

\title{
Modelling climate change impacts on grasslands and possible adaptations of liverstock systems
}

Anne-Isabelle Graux, Jean-François J.-F. Soussana, Nadine N. Brisson, David Hill, Romain Lardy

\section{To cite this version:}

Anne-Isabelle Graux, Jean-François J.-F. Soussana, Nadine N. Brisson, David Hill, Romain Lardy. Modelling climate change impacts on grasslands and possible adaptations of liverstock systems. IARU International Scientific Congress on Climate Change: Global Risks, Challenges and Decisions, Mar 2009, Copenhague, Denmark. IOP Publishing, IOP Conference Series: Earth and Environmental Science, 6, 2009, Climate change: global risks, challenges and decisions, 10-12 March 2009, Copenhagen, Denmark. 10.1088/1755-1307/6/4/242046 . hal-02751060

\section{HAL Id: hal-02751060 \\ https://hal.inrae.fr/hal-02751060}

Submitted on 3 Jun 2020

HAL is a multi-disciplinary open access archive for the deposit and dissemination of scientific research documents, whether they are published or not. The documents may come from teaching and research institutions in France or abroad, or from public or private research centers.
L'archive ouverte pluridisciplinaire HAL, est destinée au dépôt et à la diffusion de documents scientifiques de niveau recherche, publiés ou non, émanant des établissements d'enseignement et de recherche français ou étrangers, des laboratoires publics ou privés. 
P24.38

Modelling climate change impacts on grasslands and possible adaptations of livestock systems

A-I Graux(1), Jean-Francois Soussana(1), Nadine Brisson(2), D Hill(3), R Lardy(1)

(1) INRA, UR874, UREP, Grassland Ecosystem Research, Clermont-Ferrand, France

(2) INRA, UR AGROCLIM, Avignon, France

(3) Laboratory of Computer Science, Modelling and Systems Optimisation, LIMOS, Clermont-Ferrand,

France

PASIM (Riedo et al., 1998, Vuichard et al., 2007) is a biogeochemical grassland ecosystem model that simulates fluxes of $\mathrm{C}, \mathrm{N}$, water and energy at the soil-plant-atmosphere interface, as well as net primary productivity and forage intake by domestic herbivores (Figure 1). This model is being used intensively in a set of European research projects (CarboEurope IP, NitroEurope IP, CarboExtreme) aiming at understanding the $\mathrm{C}$ and $\mathrm{N}$ cycles, carbon sequestration, greenhouse gas emissions (GHG) and the effects of climate variability and climate change.
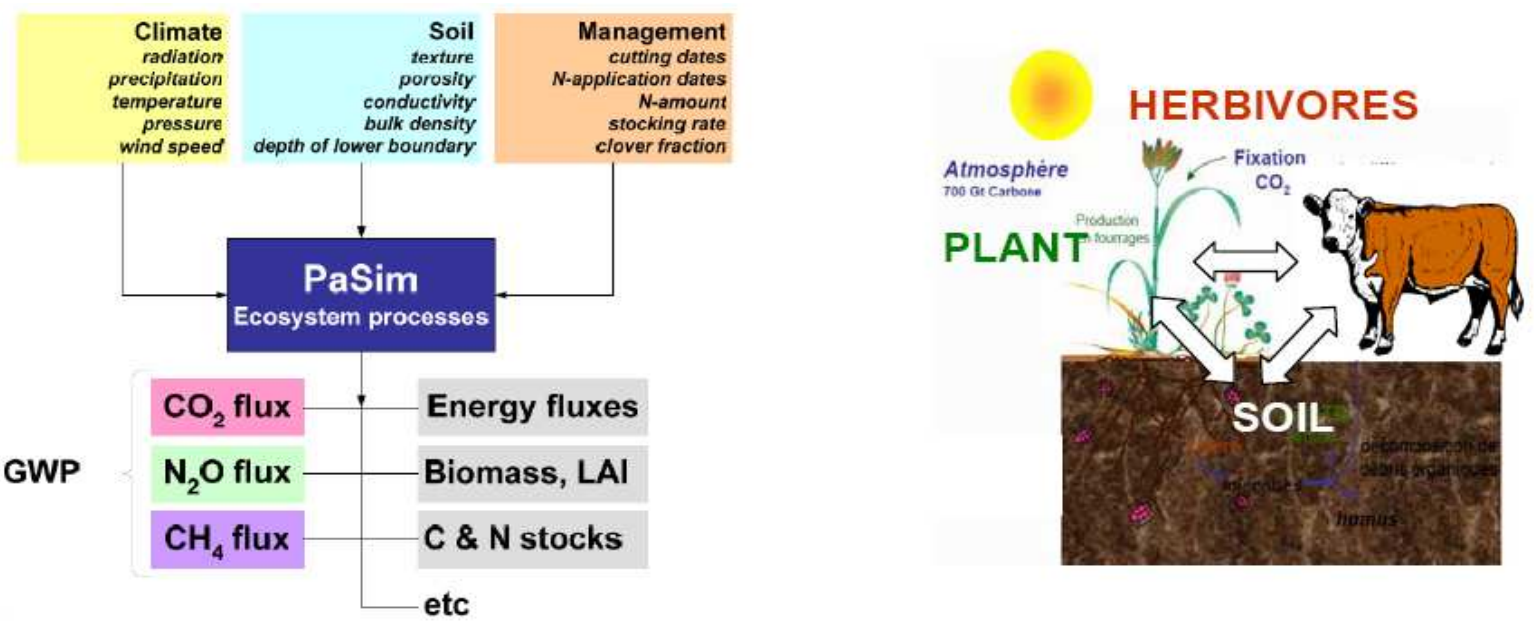

Figure 1: The Pasture Simulation Model (PASIM)

To simulate the impacts of climate change on grasslands and the adaptations, we have improved the model in order to better simulate soil temperature, $\mathrm{N} 2 \mathrm{O}$ emissions, water stress and vegetation dynamics. Moreover, management now includes irrigation and ploughing in addition to $\mathrm{N}$ fertilization, cutting and grazing, and can be either set by the user or optimized (see Vuichard et al., 2007) by the model.

The aims of this work were: a) to simulate the impacts of climate change on production, GHG emissions, carbon sequestration, water demand and test the sustainability of contrasted grassland systems; b) to identify sources of uncertainty and of variability in projections; c) to determine possible adaptations to climate change of grassland management and livestock production systems.

We have compared impact projections for a range of IPCC SRES scenarios (A1B, A2 \& B1), of climatic models (ARPEGE, GISS, NCAR, MRI, CCCMA) and of downscaling methods (anomalies, variable correction and statistical disagregation, Boé et al., 2006) at 13 French sites (Figure 2). Moreover, we have compared six grassland systems, differing by grassland type (permanent or sown, sown species, legume fraction) and by management (fertilization, irrigation, cutting and/or grazing). The agricultural practices were set at their current level for these first runs. 


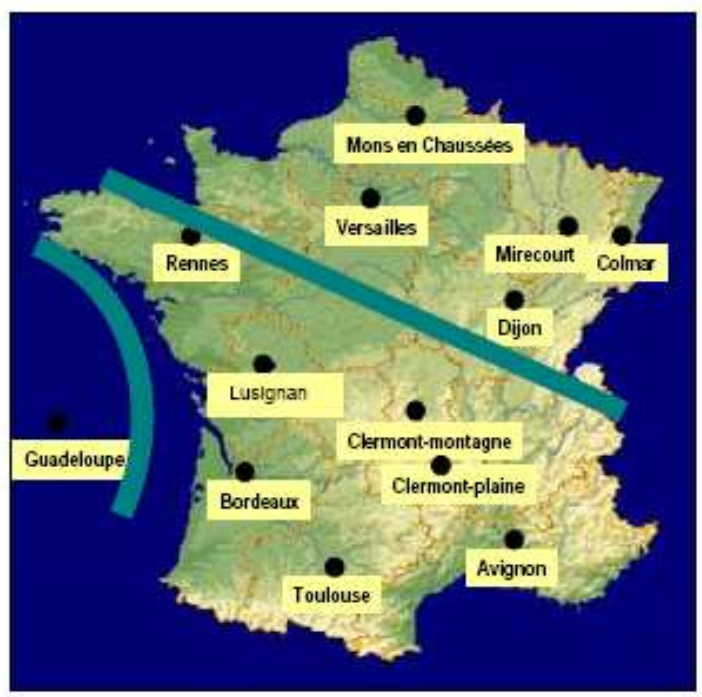

Figure 2: Grassland sites selected for projections of impacts

An example is provided for the Colmar site in Eastern France using the ARPEGE GCM model (Figure 3). Results emphasize a large effect of interannual climate variability for grassland production. When averaged over 30 yrs, future production does not vary significantly compared to the reference period (1970-2000) and there is no indication of a change in interannual yield variability according to the PASIM model. Soil organic C (SOC) content increases markedly through time, indicating that compared to the reference period the increased atmospheric $\mathrm{CO} 2$ concentration combined with warming leads to $\mathrm{C}$ sequestration according to the PASIM model. This is observed both for the extensive management (same management as during model initialization) and the intensive management (intensification of management compared to model initialization) (Figure 3).

a)

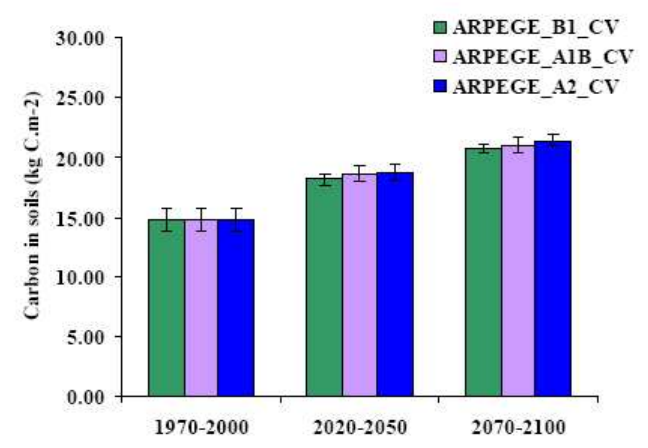

c)

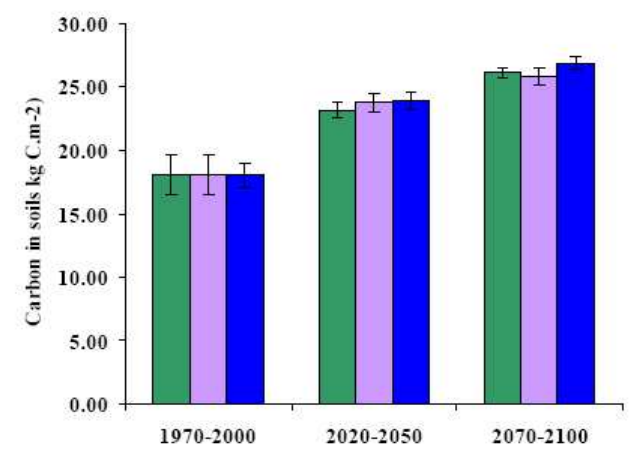

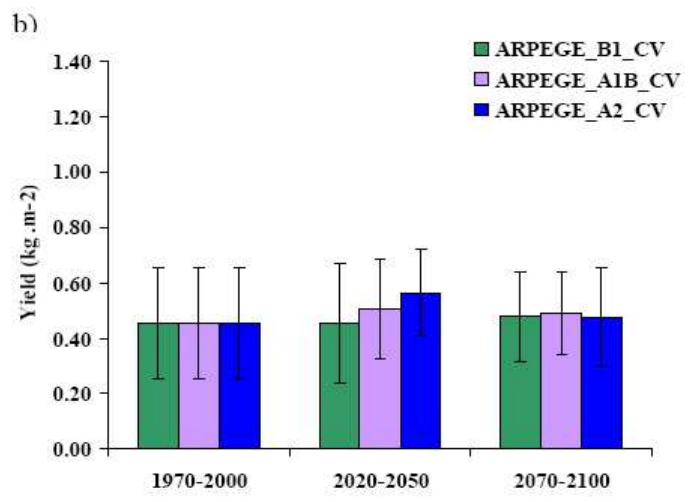

d)

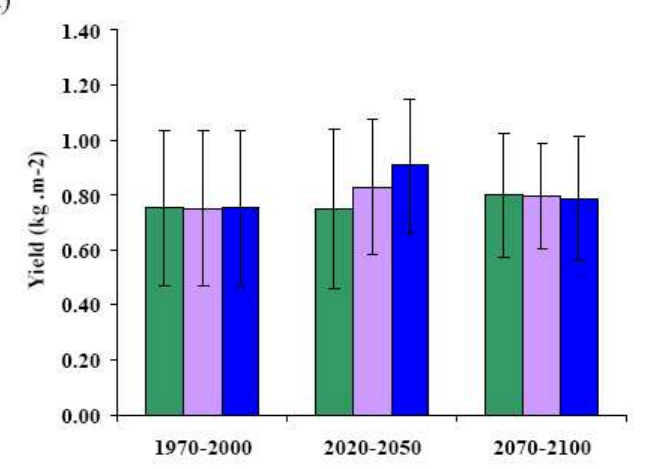


Figure 3: Projected climate change impacts at Colmar (France) of soil carbon and forage yields of a shortterm (5 yrs) grassland sown with Lolium perenne. Soil carbon was initialized at equilibrium with climate in 1950-1952 and with extensive management. a,b) extensively managed (low fertilized and not irrigated) grassland for figures; c,d) intensively managed (well fertilized and irrigated) grassland. Error bars ( \pm s.d.) show the interannual variability during the period.

A variance decomposition analysis allows comparing management and climate change variability in dry matter yield and uncertainties related to climate model, SRES scenario and downscaling methods (Table 1). Results show that climate change has a relatively small effect, compared to management and to interannual variability. Moreover, SRES and climate models introduce an uncertainty which is not to be neglected compared to the climate change signal.

\begin{tabular}{|l|c|}
\hline Factors & Weight (\%) \\
\hline Interannual variability & 100.00 \\
Management (intensive vs. extensive) & 50.18 \\
Climate change & 6.03 \\
SRES scenario & 2.99 \\
Downscaling method & 2.61 \\
GCM initialization & 0.24 \\
\hline
\end{tabular}

Table 1: Results of variance decomposition analysis for dry matter yield of a grassland sown with Lolium perenne (Colmar site). Data include the results of two management practices, three IPCC scenarios, three downscaling methods and two initializations of the ARPEGE (GCM) model. Interannual variability is used to scale variance of other factors.

Nevertheless these preliminary results should be taken with caution, in regard to current model limitations for simulations of high temperatures and of severe droughts. Model tests and parametrisation against data from climate change experiments are planned (see VALIDATE and CarboExtreme projects) and should allow more realistic projections of climate change impacts.

References

Riedo, M., A. Grub, et al. (1998). "A pasture simulation model for dry matter production and fluxes of carbon, nitrogen, water and energy." Ecological Modelling 105(2-3): 141-183.

Vuichard, N., J. F. Soussana, et al. (2007). "Estimating the greenhouse gas fluxes of European grasslands with a process-based model: 1. Model evaluation from in situ measurements." Global Biogeochemical Cycles 21(1).

Boé et al., 2006. «A simple statistical-dynamical downscaling scheme based on weather types and conditional resampling ». J. Geosphys. Res., 111, D21106. 